\title{
EXTRACTION AND QUANTIFICATION OF LIPIDS FROM BREWER'S SPENT GRAIN AND ITS POTENTIAL FOR LIPASE PRODUCTION
}

\author{
S. ORTIZ ${ }^{1}$, A. A. C. BARROS ${ }^{2}$ and A. FURIGO Jr ${ }^{1}$ \\ ${ }^{1}$ Federal University of Santa Catarina, Department of Chemical Engineering and Food \\ Engineering \\ ${ }^{2}$ Polytechnic Institute of Technology and Sciences, Luanda - Angola \\ E-mail: samaraeq@gmail.com
}

\begin{abstract}
Solid wastes from agro-industries may be used as culture medium for enzymes synthesis by filamentous fungi. The brewer's spent grain (BSG) is generated in abundance in the south of Brazil. Currently, most of this waste is used for animal feed. This work aims to extract and quantify the lipid presents in this residue. The lipids extraction was carried out by Soxhlet extraction method. Initially, the brewer's spent grain was maintained at $80^{\circ} \mathrm{C}$ for 30 minutes to remove the moisture. After, it was weighed a sample of 5 grams accurately. A flat-bottom flask, containing some glass beads, was dried at $80^{\circ} \mathrm{C}$ for 1 hour and it was weighed. The sample was introduced into the extractor unit in a sealed filter paper envelope. The solvent was added to flat-bottom flask ( $150 \mathrm{ml}$ of ethanol). The scheme was assembled and maintained on a heating mantle for 4 hours. After, flat-bottom flask was maintained at $80^{\circ} \mathrm{C}$ for the complete solvent evaporation. Then, the flask was weighed again, to determinate the lipids mass presents in 5 grams of brewer's spent grain. We can conclude that this study provides the basis for further studies, since the percentage of lipids present in this residue $(8.6 \%)$ justifies its use in experimental tests that aim lipase production.
\end{abstract}

\section{INTRODUCTION}

Lipases (glycerol ester hydrolase, E.C. 3.1.1.3) are from the hydrolases family and their main function is to hydrolyze triglycerides to produce diglycerides, monoglycerides, fatty acids and glycerol. The lipases are from animal origin (pancreatic, hepatic and gastric), vegetable or microbial origin (fungi and bacteria). Depending on its origin, the molecular mass and the enzymatic activity at different $\mathrm{pHs}$ and temperatures range (Atkinson and Mavituna, 1991; Pelizer et al., 2007).

Currently, the lipases represent approximately $5 \%$ of the world market for enzymes, with significant growth trend due their many current and developing applications (Palma et al., 2000; Saxena et al., 2011). 
Independent of their origin (plant, animal or microbial), lipases have numerous biotechnological applications in food, detergents, pharmaceutical and agrochemical industries (Sharma et al., 2001).

The brewer's spent grain is an important by-product of brewing (White et al., 2008). Mussatto and Roberto (2006) claim that the brewer's spent grain is approximately $85 \%$ of the waste generated in breweries and is commonly used for animal feed.

Mussatto et al. (2008) describe the results of the composition analysis of the brewer's spent grain from the procedure without addition of other cereals besides the malt. Santos et al. (2003) present different data for its composition, which can vary depending on the technology used in breweries, among other factors. Table 1 presents the experimental data obtained by the authors, with the percentage of dry weight. The missing values are related to components not quantified by the authors.

Table 1 - Composition of brewer's spent grain

\begin{tabular}{|l|c|c|}
\hline \multicolumn{1}{|c|}{ Component } & Mussatto et al. $(\mathbf{2 0 0 8 )}(\%)$ & Santos et al. (2003) (\%) \\
\hline Pentosans & 28,4 & 19 \\
\hline Lignin & 27,8 & 16 \\
\hline Cellulose & 16,8 & 9 \\
\hline Proteins & 15,25 & 31 \\
\hline Ashes & 4,6 & 4 \\
\hline Extractives* & 5,8 & ---- \\
\hline Acetyl group & 1,35 & ---- \\
\hline Lipids & ---- & 9 \\
\hline Starch and $\beta$-glucan & ---- & 12 \\
\hline Total & 100 & 100 \\
\hline
\end{tabular}

* consisting of waxes, fats, gums, starches, resins, tannin, essential oils and various other cytoplasmic components. Source: Adapted from Mussatto et al. (2008) and Santos et al. (2003).

There are reports in the literature about the use of agro-industrial wastes as fermentation medium for obtaining microbial lipase. Cordova et al. (1998) studied the use of sugar cane bagasse and olive cake as the medium for solid-state fermentation (SSF), conducted by the fungus Rhizopus rhizopodiformis. They obtained lipase activity of $79.6 \mathrm{U} / \mathrm{g}$ of dry residue.

Gombert et al. (1999) evaluated the lipase production by SSF using as a medium the babassu solid waste, supplemented with peptone and olive oil, and fermentation was conducted by Penicillium restrictum. The highest lipase activity $\left(30.3 \mathrm{U} / \mathrm{g}_{\text {dry weight }}\right)$ was obtained after 24 hours of fermentation. Fernandes (2007) studied the production of lipase from Burkholderia cepacia LTEB1 by SSF using as substrate wheat husk, corn cake and sunflower seed meal, separately. The highest lipase activity (240 U per gram of dry solid) was obtained using sunflower seed meal. 
In the work presented by Mahanta et al. (2008), the authors studied the production lipase by Pseudomonas aeruginosa in SSF using jatropha seed cake as substrate. The higher lipase production was in the medium increased with sodium nitrate $\left(1084.2 \mathrm{U} / \mathrm{g}_{\text {dry substrate) }}\right)$ Godoy et al. (2009) evaluated the lipase production by Penicillium simplicissimum in solid state fermentation of castor beans residue. After 96 hours of fermentation, the lipase activity resulted in $155 \mathrm{U} / \mathrm{g}$ of dry residue.

Rigo (2009) obtained lipase activity of $317 \mathrm{U} / \mathrm{g}$ using soybean meal (supplemented with $0.6 \%$ of urea plus soybean oil) as the culture medium for the SSF and the filamentous fungus Penicillium 58F. Sun and Xu (2008) studied the lipase production by SSF using the fungus Rhizopus chinensis CCTCC M201021. The fermentation medium was composed of wheat flour and wheat bran (supplemented with peptone $(2 \%, \mathrm{v} / \mathrm{v})$ and olive oil $(2 \%, \mathrm{v} / \mathrm{w}))$. The best result was $24.447 \mathrm{U} / \mathrm{g}$ of culture medium.

\subsection{Objective}

The main objective of the current study was extract and quantify the lipids present in the brewer's spent grain from breweries in Blumenau-SC, Brazil. This is an initial study, which will result in data to determining whether the brewer's spent grain has the potential to be used as a culture medium for further study in solid-state fermentation for obtaining microbial lipase.

\section{METHODOLOGY}

The lipid extraction, to quantify the same in the brewer's spent grain, was performed by Soxhlet extraction method (Castro and Priego-Capote, 2010). The BSG was obtained from different breweries, and homogenized for this experiment. Initially, the brewer's spent grain was ground and kept at $80^{\circ} \mathrm{C}$ for 30 minutes. Then, the residue remained in a desiccator to cool and an accurate sample of 5 grams was separated. A flat-bottom flask containing some glass beads were kept at $80^{\circ} \mathrm{C}$ for 1 hour, and subsequently its mass was determined.

The sample was introduced into the extractor in a stapled filter paper envelope to avoid direct contact of the sample with the solvent. As the solvent, it was used $150 \mathrm{ml}$ of ethanol, which was added to flat-bottom flask. After, the scheme was set up and it was maintained on a heating mantle.

The extraction was maintained for 4 hours. The solvent was recovered after the conclusion of the process. After, the flat-bottom flask was maintained at $80^{\circ} \mathrm{C}$ for $8 \mathrm{~h}$ for the complete solvent evaporation. Then, the flask was weighed again to determine the substrate mass extracted during the process. The Figure 1 illustrates the scheme used for the lipids extraction. 


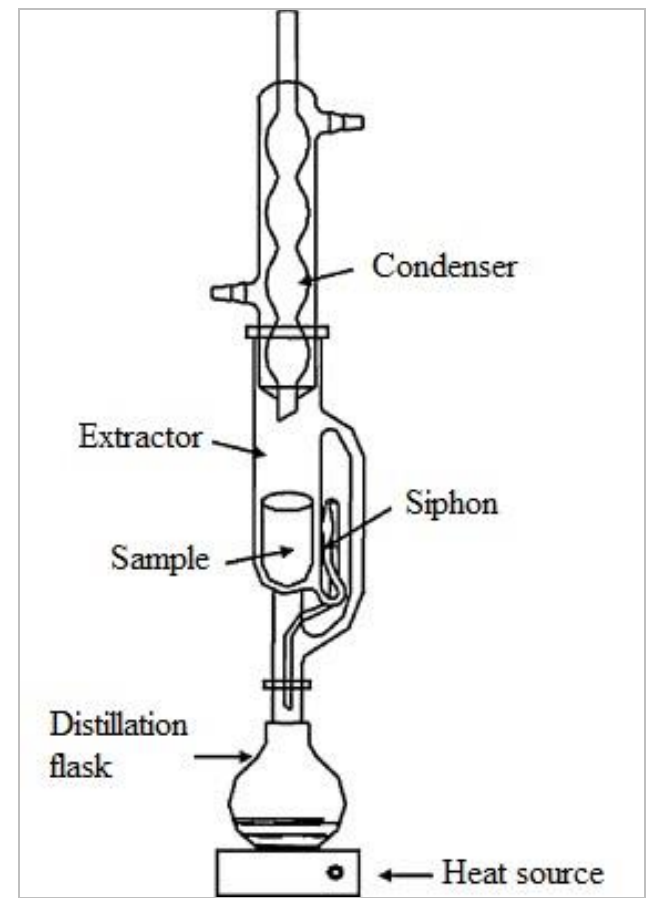

Figure 1 - Conventional scheme for Soxhlet extraction. Source: Adapted from Castro and Priego-Capote (2010).

\subsection{Calculation of Percentage of Lipids}

The difference between the weight of the flask before and after extraction corresponds to the mass of lipids presents in 5 grams of brewer's spent grain (dry weight). With this, the percentage of the lipids in the sample can be calculated according to Equation 1.

$\%$ Lipids $=\frac{\text { mass of lipids }}{5} \times 100$

\section{RESULTS AND DISCUSSION}

The step of lipid extraction from the BSG was performed in duplicate for increased reliability of results. In both cases, the difference in the weight of the flask, before and after extraction, was 0.43 grams. Applying the result obtained in the Equation 1 we have:

$$
\begin{aligned}
& \text { \%Lipids }=\frac{0,43 g}{5 g} \times 100 \\
& \% \text { Lipids }=8,6 \%
\end{aligned}
$$


The value obtained in this study approaches to the value presented by Santos et al. (2003), who reported that the brewer's spent grain valued by them contained $9 \%$ of lipids. Considering the fact that the BSG from this study is from different breweries, which do not necessarily use the same technology during the process, the result obtained is satisfactory for keeping close to the one presented in the literature. Also, considering that the addition of other ingredients during the process is unknown, which could make the BSG impure and change the amount of lipids present in the sample.

Ferraz et al. (2012) evaluated the lipase production by Sporidiobolus pararoseus using three different residues for SSF: soybean meal (8.5\% lipids), sugar cane bagasse (0.63\% lipids) and rice meal $(16.43 \%$ lipids). Lipase activities of about $130.1 \mathrm{U} / \mathrm{g}, 164.2 \mathrm{U} / \mathrm{g}$ and $189.5 \mathrm{U} / \mathrm{g}$ were obtained using soybean meal, sugarcane bagasse and rice meal as substrates, respectively, without supplementation, at $30^{\circ} \mathrm{C}$ and $60 \%$ of moisture. Based on this, the brewer's spent grain of this study (considering the composition of $8.6 \%$ lipids) shows up as a residue in potential for future studies in obtaining microbial lipase.

\section{CONCLUSIONS}

From the literature review, we can observe the industrial importance of the lipase and the growing interest in researches for its producing. The use of residues as a culture medium for the production of several enzymes is of great interest for environmental and economic issues, and we can notice that the waste variety studied is increasing, regardless of the lipids percentage in their composition.

In this context, we conclude that the brewer's spent grain is viable for future studies to obtain microbial lipase, and it should be consider the study of the medium supplementation, as well as the microorganism to be used in solid state fermentation.

\section{REFERENCES}

ATKINSON, B.; MAVITUNA, F. Biochemical Engineering and Biotechnology Handbook. 2.ed. New York: Stockton, xxix, 1271p. :il. 1991.

CASTRO, M.D. Luque de; PRIEGO-CAPOTE, F. Soxhlet extraction: Past and present panacea. J Chromatogr A, v. 1217, p. 2383-2389, 2010.

CORDOVA, J.; NEMMAOUI, M.; ISMAÏLI-ALAOUI, M.; MORIN, A.; ROUSSOS, S.; RAIMBAULT, B.; BENJILALI, B. Lipase production by solid state fermentation of olive cake and sugar cane bagasse. J Mol Catal. v. 5, p. 75-78, 1998.

FERNANDES, M.L.M. Produção de Lipases por Fermentação no Estado Sólido e sua utilização em Biocatálise. Dissertação de Mestrado. Curso de Pós-Graduação em Química - Área de Concentração em Química Orgânica, Setor de Ciências Exatas, Universidade Federal do Paraná, 2007. 


\section{9 a 22 de outubro de 2014 \\ Florianópolis/SC}

FERRAZ, Lenir Rigoli; OLIVEIRA, Daniela dos Santos de; SILVA, Marceli Fernandes; RIGO, Elisandra; LUCCIO, Marco Di; OLIVEIRA, J. Vladimir; OLIVEIRA, Débora de; TREICHEL, Helen. Production and partial characterization of multifunctional lipases by Sporobolomyces ruberrimus using soybean meal, rice meal and sugarcane bagasse as substrates. Biocatal Agric Biotechnol, v. 1(3), p. 243-252, July 2012.

GODOY, M.G.; GUTARRA, M.L.E.; MACHADO, O.L.T.; FREIRE, D.M.G. Optimization of lipase production by Penicillium simplicissimum using castor bean waste as culture medium. N Biotechnol, v. 25 (Supplement), p. S240, 2009.

GOMBERT, A.K.; PINTO, A.L.; CASTILHO, L.R.; FREIRE, D.M.G. Lipase production by Penicillium restrictum in solid-state fermentation using babassu oil cake as substrate. Process Biochem, v. 35, p. 85-90, 1999.

MAHANTA, N.; GUPTA, A.; KHARE, S.K. Production of protease and lipase by solvent tolerant Pseudômonas aeruginosa PseA in solid-state fermentation using Jatropha curcas seed cake as substrate. Bioresour Technol, v. 99, p. 1729-1735, 2008.

MUSSATTO, S. I.; ROBERTO, I. C. Chemical characterization and liberation of pentose sugars from brewer's spent grain. J Chem Technol Biotechnol, v. 81, p. 268-274, 2006.

MUSSATTO, S.I.; DRAGONE, G; TEIXEIRA, J.A.; ROBERTO, I. C. Total reuse of brewer's spent grain in chemical and biotechnological processes for production of added - value compounds. Intl Conf Exhibit Bioenerg, Portugal, 2008.

PALMA, M.B.; PINTO, A.L.; GOMBERT, A.K.; SEITZ, K.H.; KIVATINITZ, S.C.; CASTILHO, L.R.; FREIRE, D.M.G. Lipase Production by Penicillium restrictum Using Solid Waste of Industrial Babassu Oil Production as Substrate. Appl Biochem Biotechnol, v. 84-86, p. 1137-1145, 2000.

PELIZER, L. H.; PONTIERI, M. H.; MORAES, I. O. Utilização de resíduos agro-industriais em processos biotecnológicos como perspectiva de redução do impacto ambiental. J Technol Manag Innov, v. 2, n. 1, 2007.

RIGO, E. Produção e Caracterização Parcial de Lipases com Atividade de Hidrólise e de Síntese por Fermentação em Estado Sólido de Farelo de Soja. Tese de Doutorado. Programa de Pós-Graduação em Engenharia de Alimentos, Universidade Federal de Santa Catarina, 2009.

SANTOS, M.; JIMÉNEZ, J. J.; BARTOLOMÉ, B.; GÓMEZ-CORDOVÉS, C.; NOZAL, M. J. del. Variability of brewer's spent grain within a brewery. Food Chem., v. 80, p. 17-21, 2003.

SAXENA, R.K.; GHOSH, P.K.; GUPTA, R.; DAVIDSON SHEBA, W.; BRADOO, S.; GULATI, R. Microbial lipases: Potential biocatalysts for the future industry. Available in: http://www.iisc.ernet.in/currsci/jul10/articles18.htm, 2011, accessed on April 2014.

SHARMA, R.; CHISTI, Y.; BANERJEE, U.C. Production, purification, characterization and applications of lipase. Biotechnol. Adv., v. 19, p. 627-662, 2001. 
SUN, Shu Yang; XU, Yan. Solid-state fermentation for 'whole-cell synthetic lipase' production from Rhizopus chinensis and identification of the functional enzyme. Process Biochem. v. 43, p. 219-224, 2008.

WHITE, J. S.; YOHANNAN B. K.; WALKER, G. M. Bioconversion of brewer's spent grains to bioethanol. FEMS Yeast Res., v. 8, n. 7, p. 1175-1184, 2008. 